\title{
Real-time loss minimization control in induction machines based on DSP TMS320LF2812
}

- Le Minh Phuong

- Le Duc Dung

- Nguyen Viet Thuyen

- Nguyen Hoai Phong

University of Technology, VNU-HCM

(Manuscript Received on July 16 $6^{h}, 2013$; Manuscript Revised September 05 ${ }^{\text {th }}$, 2013)

\begin{abstract}
:
This paper presents a DSP based implementation of simple and very useful control algorithm for the real-time efficiency optimization of the indirect vectorcontrolled induction motor drives. Conventional field-oriented induction motor drives operate at rated flux even at low load. To improve the efficiency of the existing induction motors, it is important to regulate the magnetization flux of the motor in the desired operating range. This paper presents techniques for minimizing power loss (the copper and core losses) of induction motor based on determination of an optimum flux level for the efficiency optimization of the vector-controlled induction motor drive. An induction motor (IM) model in $d$-q coordinates is referenced
\end{abstract}

\begin{abstract}
to the rotor magnetizing current. Thus the decomposition into $d$-q components in the steady-state motor model can be utilized in deriving the motor loss model. The algorithm offers a fast convergence. The complete closed loop vector control of the proposed LMC-based IM drive is successfully implemented in real-time using digital signal processor DSP TMS320LF2812 for 1 HP motor induction motor. The close agreement between the simulation by Matlab/Simulink and the experimental results confirms the validity and usefulness of the proposed techniques. The proposed $L M C$ in a comparison with conventional FOC can reduce total losses from $5 \%$ to $67.2 \%$ for all load ranges.
\end{abstract}

Key words: Efficiency optimization, loss minimization, induction motor (IM), indirect vector control, Digital signal processor, iron loss, copper loss, Loss Model Controller (LMC).

\section{INTRODUCTION}

Produced worldwide is used by motors, mainly induction motors, which constitute around Environmental concerns, increasing energy demand, and limited resources have driven efficiency improvement in all aspects of electrical engineering. Over $50 \%$ of the electrical 
energy $60 \%$ of the industrial electrical load. The importance of the efficiency maximization for an induction motor (IM) drives may be realized from different perspectives [1], [2],[3],[4].

Induction motors are normally dimensioned for constant voltage and frequency, in such a way that they have the optimal efficiency near $75 \%$ load and almost optimal efficiency at nominal load. So, operation of an IM is very efficient at or near rated load with rated flux. However, operation with rated flux causes low efficiency at light load [2]. Thus, in cases where a motor drive has to operate in a wider load range, the minimization of losses has great significance. Efficiency optimization controls for such machines will not only earn a recurring benefit in economy but also have a very good impact on the global environment [4].[5],[7].

Electrical motor drive losses consist of grid loss, converter loss, motor loss and transmission loss. In an effort to improve efficiency, there have been improvements in the materials, design and construction techniques. However, converter loss and motor loss are still greatly dependent on control strategies, especially when the motor operates at light load. In transitional motor control the core losses and magnetizing-currentinduced stator copper loss are almost constant, so, at light load, the motor efficiency decreases drastically. However, at light loads, rated flux operation causes excessive core loss, thus impairing the efficiency of the drive. Since drives operate at light load most of the time, optimum efficiency can be obtained by programming the flux [2].

This paper presents loss-model-based controller (LMC) for minimizing power loss of induction motor and an approach of simultaneously optimizing the efficiency of induction-motor drives and selecting flux reference through the minimization of the copper and core losses while ensuring high dynamic performance. The loss-model-based controller based induction motor (IM) drive is implemented in real time for 1HP induction motor using digital signal processor DSP TMS320LF2812.

\section{LOSS MODEL OF INDUCTION MOTOR}

Losses in an IM constitute copper loss and core loss in stator and rotor, mechanical loss, and stray load loss. Core loss and copper loss depend on the magnetic and electric loading of the machine and, therefore, are controllable. The stray load loss depends mainly on the construction of the motor (type of stator and rotor slots, length of overhang, etc.) and also on the harmonics in the supply voltage [2].

Usually, for a given motor and specified load, the sum of stray load loss and the mechanical loss do not exceed $25-30 \%$ of the total losses and may be assumed to remain constant [2]. The electric loss is dominated by the copper and core losses, and when minimized, it improves the overall system efficiency. Thus, the motivation of loss minimization is to look for an optimum balance of the variable losses to make the total loss minimum. Copper loss reduces with decreasing stator and rotor currents while the core loss essentially increases with increasing airgap flux density. And a given load torque, there is an air-gap flux density at which the total loss is minimized. Hence, an electrical loss minimization process ultimately comes down to the selection of the appropriate air-gap flux density of operation. Since the air-gap flux density must be variable when the load is changing, control schemes in which the (rotor, air gap) flux linkage is constant will yield a suboptimal efficiency operation especially when the load is light. [3].

In this paper focuses in minimization stator copper, rotor copper and iron losses by determining an optimal air-gap flux density when the load is changing. An equivalent circuit for IM

\section{Trang 6}


can be varied by the different choices of flux linkage constants [6]. In this paper, we utilize an equivalent circuit referenced to the rotor magnetizing current by defining the rotor flux as $\psi_{r}=L_{m} i_{m r}$ By analysis in [5], the steady-state of induction motor equivalent in Figure. 1.
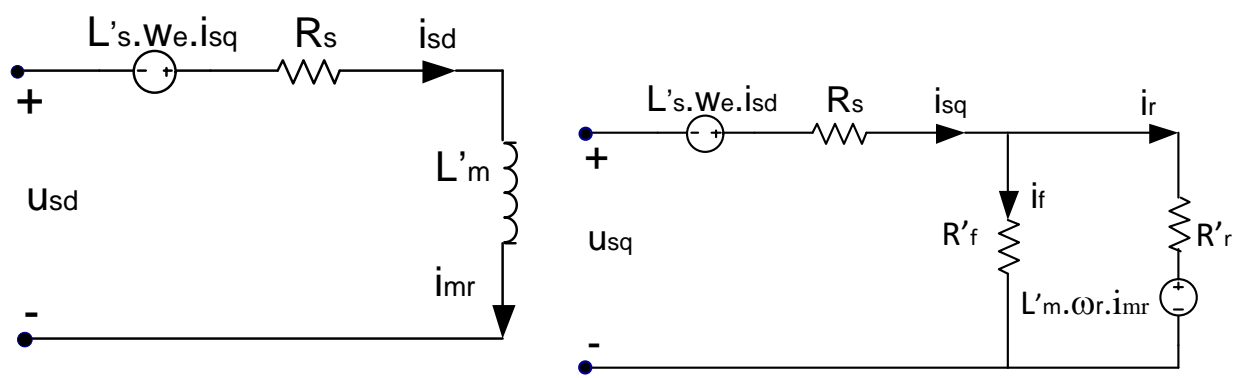

Figure. 1. Steady-state IM equivalent circuit in a field-oriented frame. (a) $d$-axis equivalent circuit. (b) $q$-axis equivalent circuit.

From figure 1, rotor magnetizing current and current through the iron loss resistor are defined by

$$
\begin{aligned}
& i_{m r}=\frac{1}{1+\mathrm{p}\left(\frac{L_{m}^{\prime}}{R_{f}^{\prime}}+\frac{L_{m}^{\prime}}{R_{r}^{\prime}}\right)} i_{s d} \\
& i_{f}=\left(p+j \omega_{e}\right) \frac{L_{m}^{\prime}}{R_{f}^{\prime}} i_{m r}
\end{aligned}
$$

Where

$\mathrm{R}_{\mathrm{S}} \mathrm{R}_{\mathrm{r}}$ : Resistances of a stator and rotor phase winding.

$\mathrm{L}_{\mathrm{s}} \mathrm{L}_{\mathrm{r}}$ : Self-inductance of the stator and the rotor.

$\mathrm{R}_{\mathrm{f}}$ : Iron loss resistor

$\mathrm{L}_{\mathrm{m}}$ : Magnetizing inductance.

$\sigma$ : Leakage factor .

$\mathrm{Z}_{\mathrm{p}}$ : Number of pole pairs.

$\omega_{\mathrm{e}}:$ Electrical rotor speed.

$\omega_{\mathrm{r}}:$ Rotor magnetizing current.

$\mathrm{i}_{\mathrm{s}}:$ Stator voltages complex space vector.

$\mathrm{u}_{\mathrm{s}}$ : Stator current complex space vector.

The induction motor losses that can be minimized by excitation adjustment are the following. The total losses of an induction motor consist of stator and rotor copper losses $\mathrm{P}_{\mathrm{cu}}$, core losses $\mathrm{P}_{\mathrm{fe}}$ and mechanical losses $\mathrm{P}_{\mathrm{m}}$. In the steady state, the stator and rotor copper losses are given by

$$
\Delta P_{\Sigma}=P_{c u s}+P_{F e}+P_{c u r}
$$

Copper losses: These are due to flow of the electric current through the stator and rotor windings and are given by

$P_{c u}=P_{c u s}+P_{c u r}=R_{s}\left(i_{s d}^{2}+i_{s q}^{2}\right)+R_{r}^{\prime} i_{r}^{2}$

Iron losses: These are the losses due to eddy currents and hysteresis, given by

$$
P_{F e}=R_{f}^{\prime}\left(i_{s q}-i_{r}\right)^{2}
$$

So, a total losses is given by

$$
\begin{aligned}
& \Delta P_{\Sigma}=P_{c u, s}+P_{i r o n}+P_{c u, r} \\
& =R_{s}\left(i_{s d}^{2}+i_{s q}^{2}\right)+R_{f}^{\prime}\left(i_{s q}-i_{r}\right)^{2}+R_{r}^{\prime} i_{r}^{2}
\end{aligned}
$$

From Figure 1, the rotor current can be expressed as

$$
\begin{aligned}
& i_{r}=i_{s q}-i_{f}=i_{s q}-\frac{R_{r}^{\prime}}{R_{f}^{\prime}} i_{r}-\omega_{r} \frac{L_{m}^{\prime}}{R_{f}^{\prime}} i_{s d} \\
& =\frac{R_{f}^{\prime}}{R_{f}^{\prime}+R_{r}^{\prime}} i_{s q}-\omega_{r} \frac{L_{m}^{\prime}}{R_{f}^{\prime}+R_{r}^{\prime}} i_{s d}
\end{aligned}
$$

Substituting from (7) into (6) yields 


$$
\begin{aligned}
& \Delta P_{\Sigma}=\left(R_{s}+\frac{L_{m}^{\prime 2}}{R_{f}^{\prime}+R_{r}^{\prime}} \omega_{r}^{2}\right) i_{s d}^{2} \\
& +\left(R_{s}+\frac{R_{f}^{\prime} R_{r}^{\prime}}{R_{f}^{\prime}+R_{r}^{\prime}}\right) i_{s q}^{2}
\end{aligned}
$$

Where

$$
R_{r}^{\prime}=R_{r}\left(\frac{L_{m}}{L_{r}}\right)^{2} L_{s}^{\prime}=\sigma L_{r} L_{m}^{\prime}=(1-\sigma) L_{m}
$$

In the steady state, a developed torque and stator of an induction motor can be defined [5]

$$
\begin{gathered}
T_{e}=\frac{3}{2} Z_{p} L_{m}^{\prime} i_{m r} i_{s q} \\
i_{s q}\left(i_{s d}\right)=\frac{2 T_{e}}{3 Z_{p} L_{m}^{\prime} i_{s d}}
\end{gathered}
$$

To minimize a power loss with a constant torque, the differentiation of the loss expression (8) has been done.

$$
\begin{aligned}
& \frac{d P_{\text {loss }}}{d i_{s d}}=2\left(R_{s}+\frac{L_{m}^{\prime 2}}{R_{f}^{\prime}+R_{r}^{\prime}} \omega_{r}^{2}\right) i_{s d} \\
& -2\left(R_{s}+\frac{R_{f}^{\prime} R_{r}^{\prime}}{R_{f}^{\prime}+R_{r}^{\prime}}\right) i_{s q}\left(i_{s d}\right) \frac{d i_{s q}\left(i_{s d}\right)}{d i_{s d}}=0
\end{aligned}
$$

Putting from (9), (10) $\mathrm{i}_{\mathrm{sq}} \mathrm{T}_{\mathrm{e}}$ into (11) leads to

$$
\begin{aligned}
& \frac{d P_{\text {loss }}}{d i_{s d}}=2\left(R_{s}+\frac{L_{m}^{\prime 2}}{R_{f}^{\prime}+R_{r}^{\prime}} \omega_{r}^{2}\right) i_{s d} \\
& -2\left(R_{s}+\frac{R_{f}^{\prime} R_{r}^{\prime}}{R_{f}^{\prime}+R_{r}^{\prime}}\right) \frac{i_{s q}^{2}}{i_{s d}}
\end{aligned}
$$

Note, in the steady state $i_{m r}=i_{\text {sd }}$ andan optimum magnetizing current level for minimum loss is given by

$i_{m r_{-} o p t}=i_{s q} \sqrt{\frac{R_{s} R_{f}^{\prime}+R_{s} R_{r}^{\prime}+R_{f}^{\prime} R_{r}^{\prime}}{R_{s} R_{f}^{\prime}+R_{s} R_{r}^{\prime}+L_{m}^{\prime 2} \omega_{r}^{2}}}$

\section{PROPOSED REAL-TIME LOSS MINIMIZATION CONTROL SCHEME}

The proposed efficiency optimization control system, which based on Field Oriented Controlis presented in Figure 2. Our target is to consider an application that requires both high dynamic performance and maximum efficiency. Therefore, an indirect vector-controlled IM drive is considered where an additional outer loop is placed for the efficiency optimization. The vector control not only has the advantage of excellent dynamic performance, but, also, due to the inherent decoupling of the -axis (flux-producing) and -axis (torque-producing) currents in the steady state, the flux control and torque control may be thought of separately. The vector control part involves speed and current controllers in the synchronously rotating reference frame, vector rotators, and reference transformations. Speed is measured by using an encoder. The reference optimal rotor magnetizing current is defined by loss-model-based controller, which has been explained in Section 2 by equation (13). 


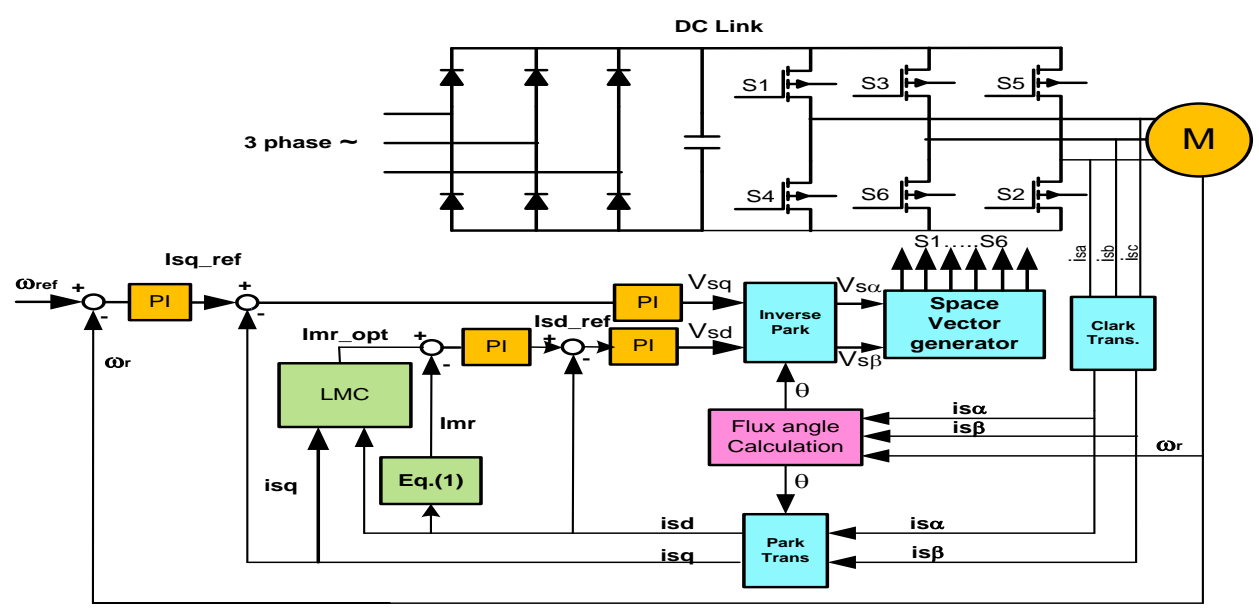

Fig. 2. The proposed control scheme based Indirect Field Oriented Controlled induction motor

\section{SIMULATION OF THE PROPOSED CONTROL SCHEME}

In order to verify the effectiveness of the proposed loss minimization scheme, a simulation model is developed in Matlab/Simulink software. Simulation has been performed $1 \mathrm{HP}$ induction motor parameters, which are presented in Table 1.The simulation is done for conventional FOC scheme and proposed loss minimization control (LMC) in three cases study to compare characteristics of these control systems) No-load starting an induction motor; b) Simulation is done at various speed levels with load torque of 5 $\mathrm{Nm}$ the motor speed is constant but load torque is changed and c) Load torque is constant but motor speed is changed.

Table 1. Induction motor data for simulation and experiment

\begin{tabular}{|l|l|}
\hline Power & $1 \mathrm{HP}$ \\
\hline Stator resistance & $13 \Omega$ \\
\hline Rotor resistance & $8.5 \Omega$ \\
\hline Iron loss resistance & $760 \Omega$ \\
\hline Number of pole pairs & 2 \\
\hline Stator leakage inductance & $0.036 \mathrm{H}$ \\
\hline Mutual inductance & $0.46 \mathrm{H}$ \\
\hline Inertia & $0.002 \mathrm{kgm}^{2}$ \\
\hline Rated speed & $1350 \mathrm{RPM}$ \\
\hline
\end{tabular}

Figures 3(a), (b) present the no-load starting transient of an experimental 1-hp induction machine whose parameters are shown in Figure 1 and the Appendix. The reference speed is ramped from 0 to $1000 \mathrm{r} / \mathrm{min}$ while seeking to minimize the total electrical loss. The simulation results show that the rotor flux linkage quickly builds up and maintains an almost constant rated value and becomes small at steady state, its near $0.2 \mathrm{~Wb}$. The total loss reduces as the developed torque becomes very small. But, in the conventional FOC scheme, the total loss is more and reaches about $80 \mathrm{~W}$ and the rotor flux linkage is rated. 


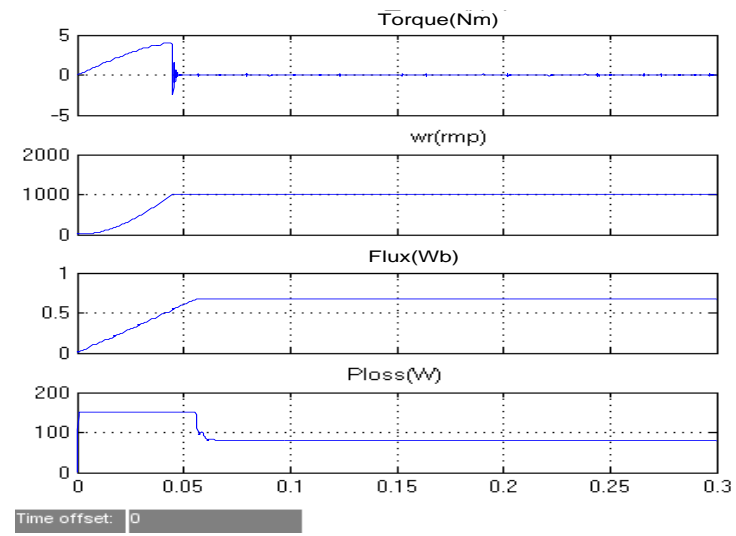

(a)

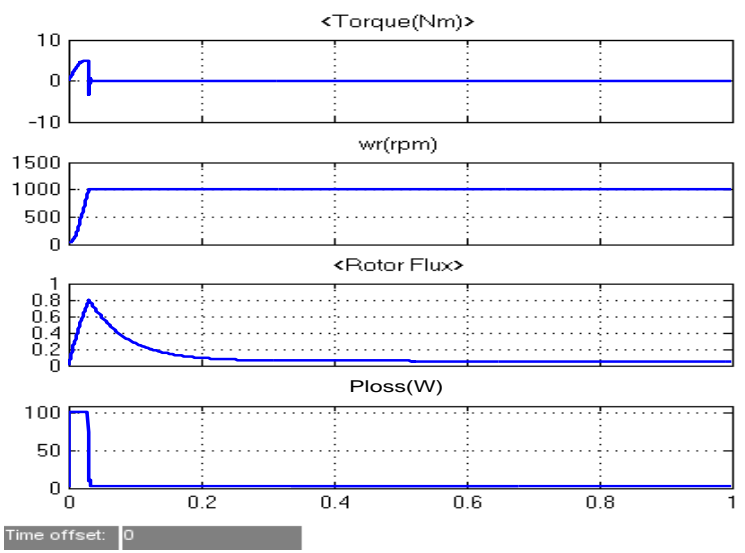

(b)

Figure 3. Motor starting from zero speed to $1000 \mathrm{r} / \mathrm{min}$. for FOC (a) and proposed LMC (b): developed torque $(\mathrm{Nm})$, actual rotor speed (rpm), rotor flux linkage (Wb), total electric loss.

Figures 4(a),(b) show the sample comparisons of total losses between the traditional FOC and the proposed LMC while the motor was running at the following constant speed $1000 \mathrm{rpm}$ and torque conditions is changing by steps: $(10 \% ; 20 \% ; 30 \% ; 40 \% ; 100 \%)$ of rated load. As expected, the rotor flux responds to the changing load demand resulting in the minimization of the losses. As the load demand decreases, the rotor flux also decreases resulting in a lower loss. Total loss of induction motor in the proposed LMC is less than in a conventional FOC by each load. 


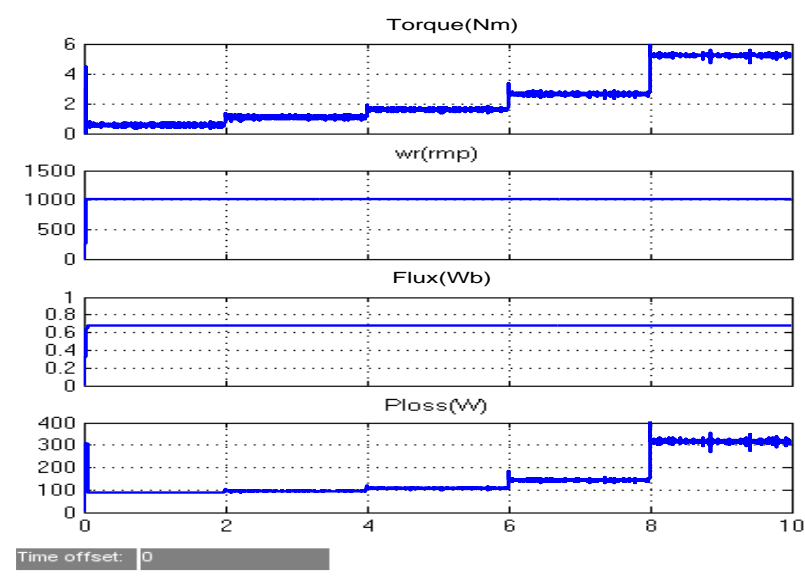

(a)

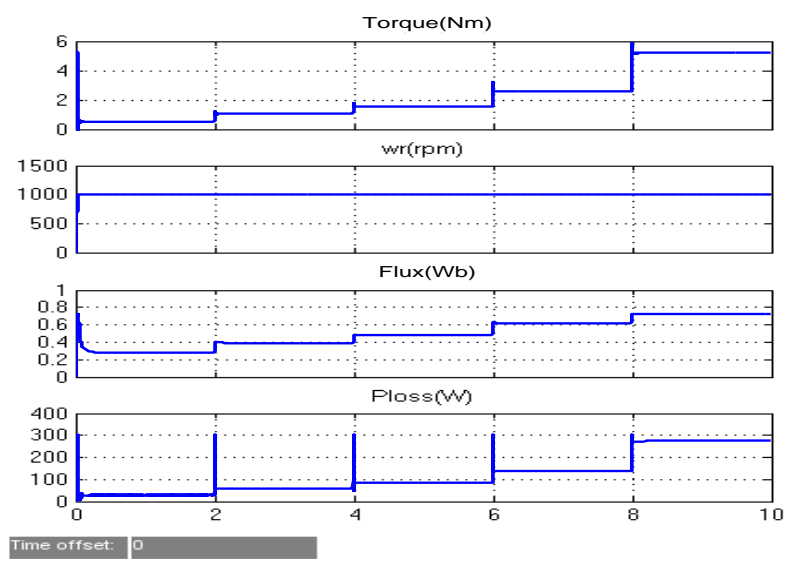

(b)

Figure 4. Motor control and loss minimization for changing rotor speed for FOC (a) and for proposed LMC (b): developed torque $(\mathrm{Nm})$, actual rotor speed $(\mathrm{rpm})$, rotor flux linkage $(\mathrm{Wb})$, total electric loss.

In Figure 5(a),(b) the rotor speed is changed with time by steps $(20 \% ; 40 \% ; 60 \% ; 80 \% ; 100 \%)$ of rated speed and load torque is $10 \%$ of rated. The figures demonstrated, the rotor flux linkage and the loss seek the minimum level. In proposed control, flux responds to the changing speed, and below the rated flux. Total loss of the proposed LMC is less than of conventional FOC by each speed level. 


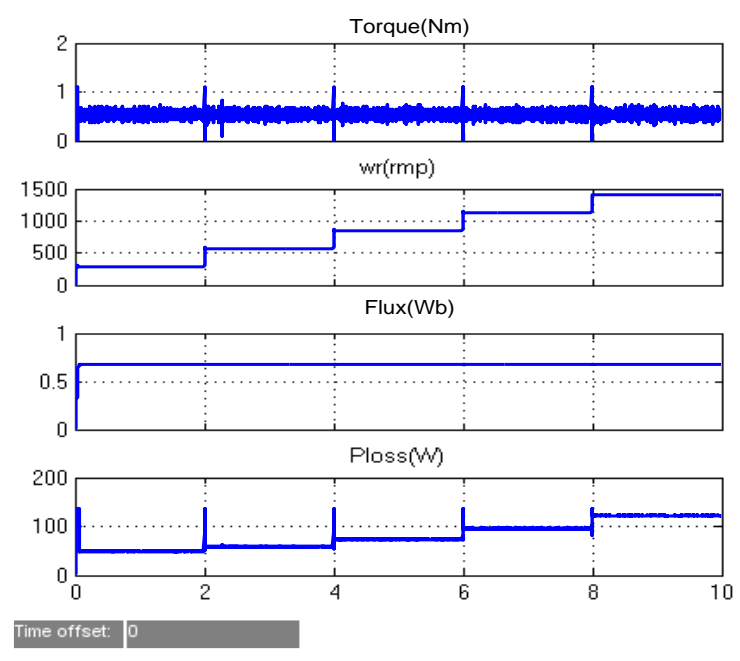

(a)
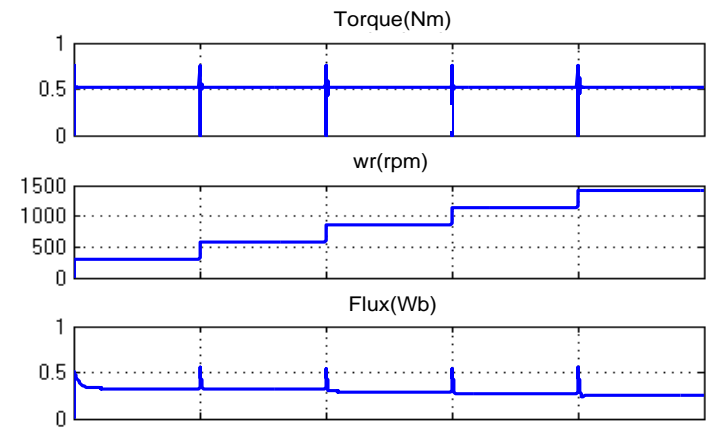

Ploss

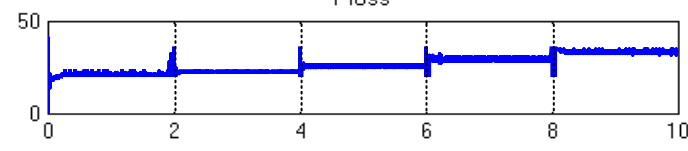

ime offset:

(b)

Figure 5. Motor control and loss minimization for changing rotor speed for FOC (a) and for proposed LMC (b): developed torque $(\mathrm{Nm})$, actual rotor speed (rpm), rotor flux linkage $(\mathrm{Wb})$, total electric loss

Figures 3-5 demonstrate the possibilities that this proposed control scheme presents-changing load or reference speed commands appropriate flux linkage to minimize the electric loss while giving high-performance speed control. The total losses and efficiency of an induction motor forproposed LMC and conventional FOC are shown in table 2 and table 3 . The simulation results are plotted in figure 6 and figure 7 .

\section{Trang 12}


Table 2. The simulation result: A comparison total loss for two control schemes with various loads, a constant speed equal $1000 \mathrm{rpm}$

\begin{tabular}{|c|c|c|c|}
\hline \multirow{2}{*}{$\begin{array}{c}\text { Load }(\%) \\
\text { Of rated }\end{array}$} & FOC & Proposed LMC & \multirow{2}{*}{$\begin{array}{c}\text { Comparison } \\
(\%)\end{array}$} \\
\cline { 2 - 3 } & $\Delta \mathrm{P}_{\Sigma}(\mathrm{W})$ & $\Delta \mathrm{P}_{\Sigma}(\mathrm{W})$ & 67.2 \\
\hline 10 & 82 & 27 & 40.0 \\
\hline 20 & 90 & 54 & 19.0 \\
\hline 30 & 100 & 81 & 13.8 \\
\hline 40 & 118 & 103 & 5.48 \\
\hline 100 & 310 & 293 & \\
\hline
\end{tabular}

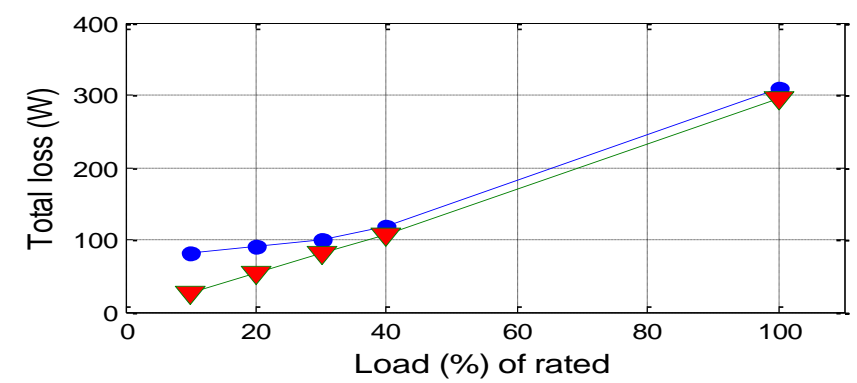

Figure 6. Comparison of total loss with and without the proposed LMC

Table 3.The simulation result: a comparison of total losses for two control schemes with various speed levels and constant load torque $10 \%$ of rated

\begin{tabular}{|c|c|c|c|}
\hline \multirow{2}{*}{ Speed (\%) Of rated } & \multicolumn{1}{|c|}{ FOC } & Proposed LMC & \multirow{2}{*}{ Comparison (\%) } \\
\cline { 2 - 3 } & $\Delta \mathrm{P}_{\Sigma}(\mathrm{W})$ & $\Delta \mathrm{P}_{\Sigma}(\mathrm{W})$ & 56.5 \\
\hline 20 & 46 & 20 & 60.2 \\
\hline 40 & 56 & 22 & 65.1 \\
\hline 60 & 72 & 25 & 68.5 \\
\hline 80 & 92 & 29 & 72.2 \\
\hline 100 & 118 & 33 & \\
\hline
\end{tabular}

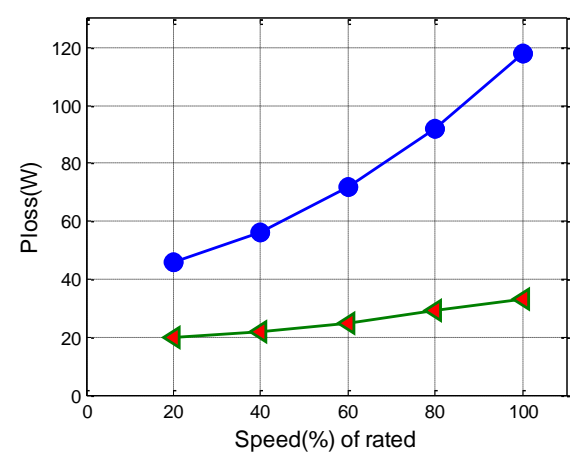

Figure 7. Comparison of total loss with and without the proposed LMC 
When the proposed LMC is utilized, a slight reduction in total losses is observed while there was no difference in the dynamic performance of the controller. Thus, the improvement of the proposed method is verified. It is observed that the proposed scheme has smaller loss factor than the traditional one in all the speed ranges, which indicate reduced loss for the proposed LMC.

\section{HARDWARE IMPLEMENTATION AND EXPERIMENTAL RESULTS}

In order to implement the proposed LMC in real time the DSP TMS320LF2812is used. To simplify code development and shorten debugging time, a Code Composer Study tool is provided. In addition, an onboard JTAG connector provides interface to emulators. The DSP is supplemented by a set of on-board peripherals used in digital control systems including analog to digital (A/D), digital to analog (D/A) converters, digital I/O, serial interface and incremental encoder interfaces.The block diagram of experimental system is shown in Fig. 8.

The PC-based controller produces numerical switching commands sent to DSP board and outputs of the DSP board are sent to the base drive circuit to drive the inverter. The actual motor currents are measured by the Current sensors HX-05-P and fed back to the DSP board through the A/D channel system.

Rotor position is sensed by an optical incremental encoder of 2000-line resolution and is fed back to the DSP board through the encoder interface. The IM is coupled to a dc machine. The $\mathrm{dc}$ machine is operated as a generator in order to adjust load to the IM.

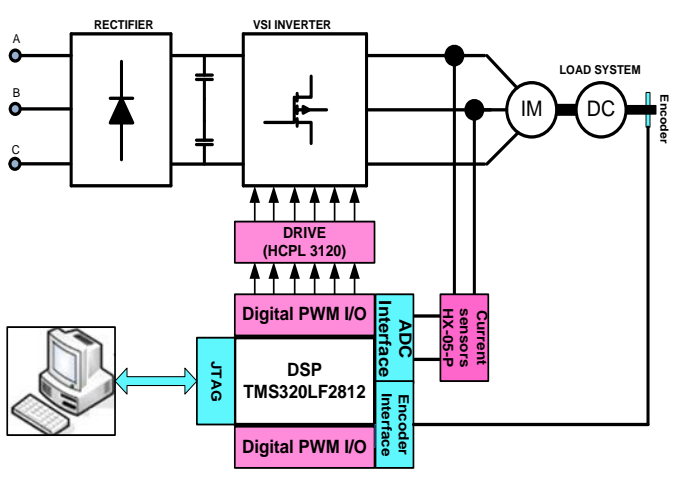

Figure. 8. Block diagram of experimental

The control algorithms are implemented through developing a real-time Simulink model. Then the model is downloaded to the DSP board utilizing Control Desk software and real-time workshop (RTW). The Graph Tool of Code Composer Studio software is provided to observe experimental results online in PC by JTAG interface between DSP2812 and PC.

\section{EXPERIMENTAL RESULTS.}

In order to further investigate the effectiveness of the proposed LMC, real-time experiments are carried out on the available $1 \mathrm{HP}$ motor. The parameters of this motor are obtained through no load test and locked rotor test, and shown in Table 1. Figures 9-10 show experimental results of conventional FOC and the proposed LMC, is consists of the developed torque, speed, magnetizing current command, and total. The motor is operated at $1000 \mathrm{rpm}$ and torque conditions is changing by steps: $(10 \% ; 20 \% ; 30 \%$; $40 \%$ ) rated load torque by every 20 s. One can see that the speed and developed torque remains same regardless while the total loss is reduced. 


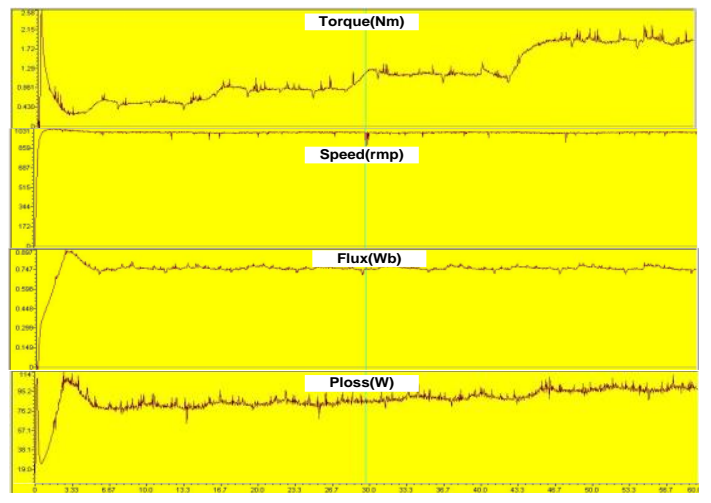

Figure 9. Experimental results with conventional FOC: developed torque $(\mathrm{Nm})$, actual rotor speed (rpm), rotor flux linkage $(\mathrm{Wb})$, total electric loss

To investigate the effects of proposed LMC at different speeds, the motor is operated at various speeds under the same $10 \%$ of rated load torque. Operation of an IM is very efficient at near or rated conditions. In this case, the proper selection of the flux level in the motor can achieve the energy saving. For this reason, the experiment was carried out at light load (10\% of the rated torque) rather than the rated torque in order to clearly demonstrate the effectiveness of the proposed loss minimization scheme. The total power loss is calculated using (6) and fed for ease of getting stable measurement in real-time.

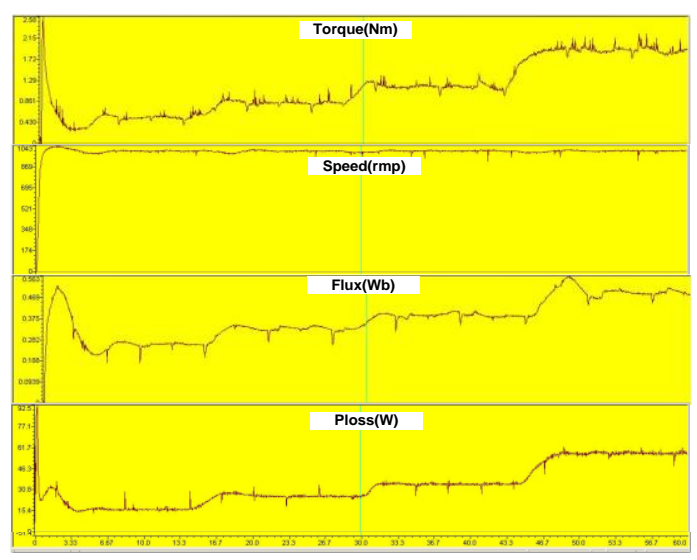

Figure 10. Experimental results with proposed LMC: developed torque $(\mathrm{Nm})$, actual rotor speed (rpm), rotor flux linkage (Wb), total electric loss.

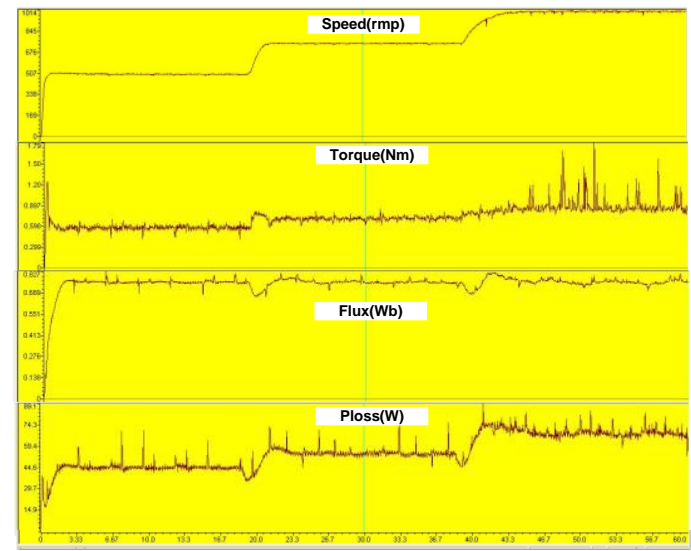

Figure 11. Experimental results with conventional FOC: actual rotor speed (rpm), developed torque $(\mathrm{Nm})$, rotor flux linkage $(\mathrm{Wb})$, total electric loss.

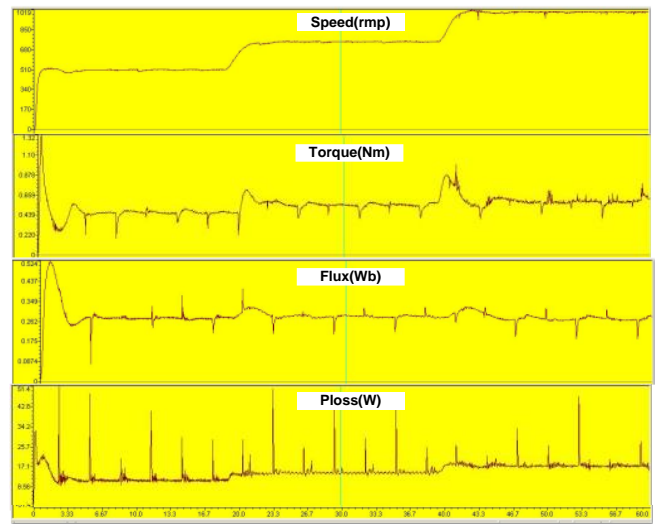

Figure 12. Experimental results with proposed LMC: actual rotor speed (rpm), developed torque $(\mathrm{Nm})$, rotor flux linkage $(\mathrm{Wb})$, total electric loss.

Figure13-14 show experimental results: the comparison of total loss and efficiency between the IM drive by a conventional FOC and the proposed LMC. It is found that the proposed LMC provides significant reduction in total loss over the conventional FOC. The tables show the experimental results of percentage loss deduction of the proposed LMC as compared to the conventional scheme at different load and different speeds. 


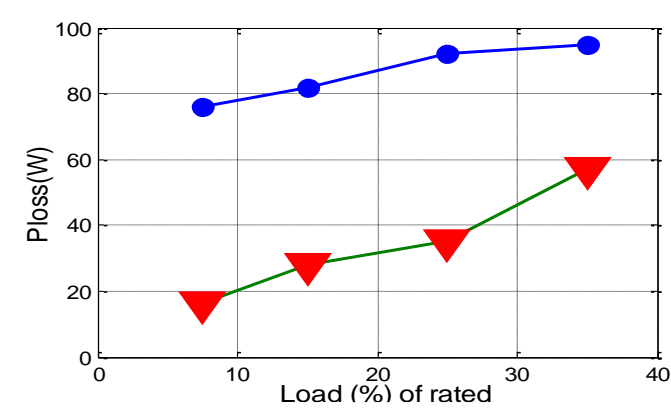

Figure 13. The comparison efficiency of two control schemes with various loads and a speed $1000 \mathrm{rpm}$

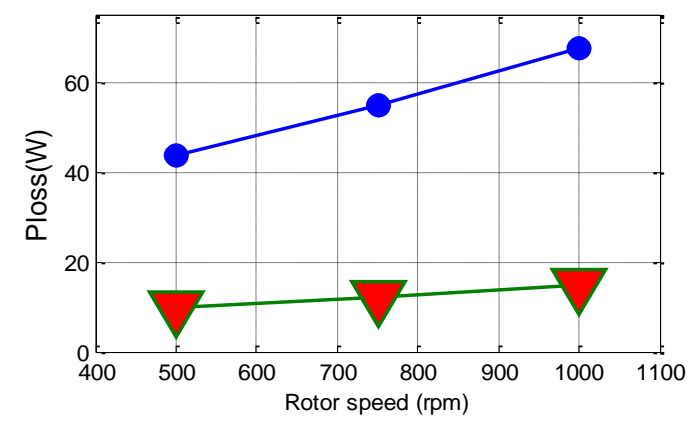

Figure 14. The comparison efficiency of two control schemes with various speed levels and constant load torque $10 \%$ of rated

\section{CONCLUSIONS}

A new online loss-minimization-based controller for IM drive has been developed and presented in this paper. The complete closed loop vector control of the proposed LMC-based IM drive is successfully implemented in real-time using digital signal processor DSP TMS320LF2812 for 1HP motor induction motor. The performance of the proposed controller has been tested in both simulation and experiment at different operating conditions. It is found from the results that the performance of the drive with the proposed LMC has been improved in terms of power saving as compared to a conventional FOC. The performance of the drive is tested only in steady state, as any industrial drive runs in steady state for a long time and hence the steadystate loss is the main concern for drives. A comparison of the proposed LMC with the conventional FOC showed that the proposed LMC can results in higher loss reduction in all speed ranges as compared to the conventional one. The proposed LMC in a comparison with conventional FOC can reduce total losses from $5 \%$ to $67.2 \%$ in depending on load, and the total loss can be reduced significant, specially, and can reach to $72 \%$ when load is about $10 \%$ of rated load.

\section{Trang 16}




\section{Điều khiển trực tuyến giảm tốn hao trong động cơ cảm ứng trên cơ sở DSP TMS 320 LF2812}

- Lê Minh Phương

- Lê Đức Dũng

- Nguyễn Viết Thuyên

- Nguyễn Hoài Phong

Trường Đại Học Bách Khoa, ĐHQG-HCM

\section{TÓM TÁT:}

Bài báo trình bày ứng dụng giải thuật điều khiển trực tuyến tối ưu hóa hiệu suất động cảm ứng đơn giản và hiệu quả trên cơ sở DSP thông qua mô hình điều khiển dựa vector từ thông rôto (FOC). Theo phương pháp điều khiển truyền thống động cơ cảm ứng, từ thông của động cơ được giữ không đổi và bằng định mức ngay cả khi non tải, vì vậy hiệu suất sẽ rất thấp. Để nâng cao hiệu suất của động $c^{\circ}$, viêc quan trọng là điều chỉnh từ thông động cơ theo tải. Trong bài báo có trình bày kỹ thuật giảm thiểu tổn thất điện năng (trong cuộn dây và trong lõi sắt) của động cơ cảm ứng dựa trên xác định giá trị từ thông tối ưu. Mô hình toán của hệ được

\section{REFERENCES}

[1]. N. Lane and D. F. Boesch. Vision 2033, part 6: Energy, the environment, and global change. The American Association for the Advancement of Science [Online]. Available: http://fellowships.aaas.org/ PDFs/Visions_Book/07_Part_6.pdf, (2004).

[2]. ChandanChakraborty, Yoichi Hori, Fast Efficiency Optimization Techniques for the mô tả trong hệ quy chiếu dq với dòng điện từ hóa tham chiếu. Giải thuật trình bày trong bài báo đảm bảo đáp ứng động nhanh. Mô hình điều khiển vector vòng kín với giải thuật điều khiển giảm tổn hao trực tuyến (LMC) được thực hiện thành công dựa trên kỹ thuật xử lý số tín hiệu DSPTMS320LF2812 cho động co cảm ứng công suất định mức $1 \mathrm{HP}$. Sự đồng nhất giữa kết quả mô phỏng bằng Matlab/Simulink và các kết quả thực nghiệm xác nhận tính đúng đắn và tính hữu dụng của giải thuật đề xuất. Giải thuật điều khiển $\angle M C$ so với giải thuật $F O C$ truyền thống cho phép giảm tổn hao từ $5 \%$ đến $67.2 \%$ với các tải khác nhau.

Indirect Vector-Controlled Induction Motor Drives .IEEE Transactions on industry applications, Vol. 39, No. 4, July/August 2003, 1070-1076.

[3]. Gan Dong, OlorunfemiOjo, Efficiency Optimizing Control of Induction Motor Using Natural Variables. IEEE transactions 
on industrial electronics, vol. 53, no. 6 , December 2006, 1791-1800.

[4]. Le Minh Phuong, Truong Minh Trieu, Le DinhKhoa, A New Online Efficiency Optimization Field Oriented Control For Induction Motors Based On Fuzzy Logic Technique, ISEE 2011, 478-485.

[5]. M. Nasir Uddin, Sang Woo Nam, New Online Loss-Minimization-Based Control of an Induction Motor Drive. IEEE transactions on power electronics, Vol. 23, NO. 2, March 2008, 926-933.

[6]. S. Yamamura, AC Motors for HighPerformance Applications. New York: Marcel Dekker, (1986).

[7]. J. Malinowski, J. McCormick, and K. Dunn, Advances in construction techniques of $A C$ induction motors: Preparation for superpremium efficiency levels, IEEE Trans. Ind. Appl., vol. 40, no. 6, 1665-1670, Nov./Dec. (2004). 